\title{
Gifted amongst Preschool Children: An Analysis on How Teachers Recognize Giftedness
}

\author{
Letícia Fleig Dal Forno, Sara Bahia, Feliciano Henriques Veiga \\ University of Lisbon
}

\begin{abstract}
The aim of this research is to expose what teachers from two different cultures observe as characteristics of giftedness in preschool children. The research also depicts the teachers' conception of inclusive gifted education. The applied qualitative methodology is based in an interview, which focuses on understanding teachers' difficulties and perceptions in identifying and recognizing a gifted preschool child. Eight teachers, from Brazil and Portugal, participated in this study. Teachers' answers were analyzed through a formal content analysis procedure. The results indicate that teachers acknowledge the concept of giftedness; they analyze the engagement and the behavior of the children through the characteristics most present in literature. However, understanding what the gifted child needs is still difficult for teachers. This study indicates that teacher training needs to be more specific about the concept and the identification of the gifted children during the preschool years.
\end{abstract}

\section{Introduction}

This study aims to expose what teachers from two different cultures observe as characteristics of giftedness in preschool children. The applied qualitative methodology is based in an interview, which focuses on understanding teachers' difficulties and perceptions in identifying and recognizing a gifted child. According to Heller, knowing what teachers understand about giftedness and how they recognize gifted students is important [13]. Pérez and Freitas describe that teachers play a significant role in the recognition and evaluation processes of the gifted student [16]. In this study, the research problem focuses on how and based on what preschool teachers define the giftedness and the gifted student.

In the second section, we contextualize the concept of giftedness with the educational background. In the third section, we describe the methodology used in this study. The fourth section contains the obtained results, which are further discussed in the fifth section. We present the
Conclusions reached with this research in the sixth section.

\section{Context}

This section introduces and contextualizes the concept of giftedness, according to formal definitions, the educational context, and the screening and signalization of giftedness in preschool. Additionally, at the end of this section, we associate the concept of giftedness to the concept of inclusive education.

\subsection{Giftedness}

The concept of giftedness is multidimensional, and involves characteristics related to personality, cognition, and behavior. Non cognitive features have recently begun to be understood in the study of giftedness as a set of psychological dimensions of different kinds [2]. In spite of the advances in research during the past decades, theories of giftedness have different perspectives about what giftedness is and how to identify a gifted individual. Over three decades ago, Renzulli described giftedness in the Three Ring Model, exposing three characteristics which any gifted individual has: task commitment, creativity and above average ability [19].

Gagné described giftedness in his Differentiated Model of Giftedness and Talent - DMGT - as an expression of a natural talent capacity $[10,11]$. The gifted student has a natural ability, and is influenced by environmental and intra-personal catalysts that enable the gifted potential to be transformed into a talent, according to Gagné [10]. Thus giftedness is seen as a confluence of biological determinants and environmental factors, namely educational opportunities. In this sense, giftedness is not something that is possible to train during development through a process of repetition within a specific domain. It is a natural expression which a person has in his/her learning process that must be nurtured and nourished [10].

Renzulli [18] explained giftedness as a potential in individual development which has significance in learning and in the productions that the individual 
elaborates in any area. Therefore, the relation of giftedness and the area of development (logical, linguistic, emotional, artistic, and physical) is, for the individual, an opportunity for her/him to express interests and abilities [18]. Consequently, educational opportunities are of utter importance for the expression of giftedness.

\subsection{Giftedness in school}

In the educational context, the definition of giftedness is based on the significance of the expression of an above average potential that impacts on the student's development and learning in school $[10,14,16]$. The difference of pace and performance highlights gifted children's skills and abilities [8, 11]. These skills and abilities are recognized through the giftedness own fields and areas of interest [11, 18]. Such characteristics are truly significant for the gifted student and determine the challenges and motivations that promote creative productions $[7,8$, $10]$.

Another feature which is important to further understand giftedness is intelligence. Literature presents distinct concepts of giftedness depending on the underlying concept of intelligence. We may consider two types of gifted - Academic or creativeproductive - according to Renzulli [18]. Heller describes giftedness as the concept(s) area(s) of interest of the gifted [13] whereas Gagné describes it as the expression of a natural potential of the individual [10]. The way giftedness is perceived in function of the conception of intelligence is relevant for understanding the impact of education in the development of the gifted child's potential and wellbeing.

According to Heller [13], teachers need to understand the relationships between the student's domain areas, skills, and potential to properly identify giftedness because the activity proposed by the teacher may incite a student to express his/her gifted characteristics [14]. However, this expression may be in the same domain or in different domains of knowledge [13].

Besides intelligence, as the definitions of giftedness suggest, other personal dimensions must be taken into account. From an educational perspective, giftedness can be defined as the expression of patterns of differentiated learning and a potential that allows the gifted student to solve problems and challenges in a different way, showing unexpected ideas, through their autonomy and understanding abilities [2]. This potential relates to cognitive dimensions as well as motivational, emotional and social aspects. In this sense, giftedness is a characteristic of the learners' performance, characterized by the particularities of the individuals in relation to their cognitive, affective and moral level, as well as their interests, choices and attitudes [15].

Research has shown that teachers' perceptions of giftedness include some more specific features such as: creativity, curiosity, as academic talent, motivation, fast and easy learning, learning initiative, and extensive knowledge, [3, 14, 15]. Moreover, research has also shown that the perception of giftedness includes definitions, conceptions, characteristics, theoretical frames of reference, and many other features related to giftedness and the gifted. Therefore, when assessing teachers' perceptions of giftedness, it is necessary to take into account what teachers understand about giftedness and who is for him/her a gifted student $[4,13]$. In this way, the teacher's perception of giftedness is essential for the recognition of his/her gifted students.

For some authors it is important to understand the perception of giftedness that teachers have from a theoretical perspective $[4,8,13]$. If the teacher has the opportunity to explain what he/she knows about the subject giftedness, it is possible to understand what is the underlying theory that is mentioned and which characteristics of giftedness he/she recognizes and values in the students $[8,13]$. The perception teachers have of giftedness and the competence teachers have in recognizing, in a student, characteristics of giftedness and therefore dealing with those specific features is important for the wellbeing of gifted students in all levels of teaching. However, the younger the child, the better, because the impact in development is greater when the child is still young, particularly before entering compulsory schooling.

\subsection{Screening and identification of giftedness in preschool}

Preschool is 'the window' of opportunity for the development of the individual and is the main source of learning outside the family context, thus being the other space besides the family where the child can learn [7]. The child's learning and educational process is determined by individual characteristics, strategies, attitudes, and skills as well as his/her levels of interest and prior knowledge [9]. That is why research on education considers different contexts and different spheres of development when studying the preschool years. Most research stresses the facilitators of development. However, especially since the concept of inclusive education has gained widespread relevance, the focus on developmental barriers is also important when considering all factors that impact in development of the full potential of students.

In an inclusive education the specific needs of all children must be met. All children have a right to be educated and to be challenged and supported in their 
learning. In almost every country, with the exception of Portugal after 2008, giftedness is considered a special need due to the specific challenge gifted students face and because any gifted child needs to learn and be engaged in school. Many students do not have the opportunity to be challenged in their school learning. The younger the child, the more repetitive and unchallenging the school curricula is. Preschool may be particularly straightforward and monotonous for a talented and gifted child.

During the preschool years, because of the particular features of this stage of schooling and development, it is important to start by identifying both the facilitators and barriers to a truly inclusive education. Considering the specific needs of all children enables the full development of any child because most of these are attitudinal barriers that we create on our minds [1]. Attitudinal barriers may impact on learning and participation because they are implicit in the teacher's perceptions of learning differences [5]. Moreover, it is known that classroom teachers that accept and deal with the concept of inclusion in a positive way, that are perceptive to students' needs, that have a flexible attitude and are open to new ideas are facilitators of inclusion and truly promote children's development [1].

In terms of giftedness, the preschool child can be recognized by his/her teacher as exhibiting potential giftedness or can be labeled as gifted, and go through the accessibility and inclusion process in the classroom [17]. For this screening and identification the educator needs to understand the special educational needs and challenges that lead to accurate adjustments and enable the gifted child to feel integrated and recognized [19]. Preschool children should not be diagnosed as gifted, but signaled through their characteristics, specificities and development [17].

The recognition of giftedness in childhood education is complex due to the lack of incentive to early identification of potentially talented children [19]. But the identification may be structured according to the teacher's ability to understand that the concept entails features that can be easily observed in the developmental process offered by this educational phase [19]. Therefore, there are special aspects in childhood education that should be analyzed in the child: curiosity, enthusiasm in learning, developmental ease, opportunities of creative expression in different domains, social relations, and means of expression [17]. These aspects are related to theories of giftedness and abridge cognitive as well as motivational, emotional, and social components.

\subsection{Gifted students and inclusive education}

It is consensual that descriptions of giftedness involve school inclusion of a student who has specific needs in the development and in the learning [20]. Taking into account different learning abilities, paces or rhythms in the classroom necessarily implies differentiation of subjects in school as well as of learning objectives. Thus, inclusion for the gifted student is about understanding the individuals, their specificities and their motivation and engagement in learning [5, 15].

However, this need is not met for many gifted children [18]. Bearing in mind the importance of the recognition of giftedness by teachers and the importance of teachers recognizing and supporting the specific characteristics that gifted students have, it is important to fully understand how the preschool teachers perceive giftedness and gifted characteristics. In recognizing both, teachers are more prone to help gifted preschool children adjust to their school and family environment and may have profound impact in the future of these children.

In sum, literature points out the importance of the way teachers perceive giftedness, recognize gifted characteristics in some of their students and intervene on the development of a gifted student through acceptance and support.

\section{Methodology}

In this section, we describe the qualitative methodology used in this research, as well as the instrument that was employed, the procedure, and the participants. This study presents partial results of a broader research that aimed at investigating the perception of early childhood Brazilian and Portuguese teachers about giftedness and creativity. Specifically, the part of the larger research that uses a qualitative method is presented in order to reveal teachers' perceptions of giftedness and inclusion. The applied qualitative methodology is based on an interview aiming at understanding the perceptions and difficulties of teachers in the identification and recognition of gifted children and of their specific educational needs. The aim of this research is, thus, to expose what teachers conceive as giftedness and observe as characteristics of giftedness in children's actions in preschool as well as their conception of inclusion. Teachers' answers were analyzed through a content analysis procedure [6]. Two judges confronted the categories and reached a total agreement. 


\subsection{Instrument}

The interview developed in this research comprised 6 questions about three subjects: giftedness, creativity, and inclusion (special needs). Specifically for this study, we analyzed the questions involved the subject of giftedness and the subject special needs. All the questions were based on previous researches. The research questions of the interview hereby analyzed were three specific questions about giftedness in general and the special needs:

a) How is the recognition of a student with special educational needs and how to approach the work in the classroom?

b) As can be recognized in childhood education gifted students? There are specific moments?

b.1) had experience with gifted students in your classroom? How many? How would you characterize?

b.2) why or how would you describe recognizing giftedness in students?

b.3) do you feel that your school is an incentive for recognizing gifted students?

b.4) and can the school promote actions with educators and children in order to encourage this student?

\subsection{Procedure}

The procedure of this study was conducted in two phases: 1. Interview of Brazilian teachers in April 2013; 2. Interview of Portuguese teachers in December 2013. Each interview did not last more than 45 minutes. Five teachers from each country were invited, but two of Portuguese teachers declined.

\subsection{Participants}

The study included 8 preschool teachers from Brazil $(\mathrm{N}=5)$ and from Portugal $(\mathrm{N}=3)$ acting with children from three to five years of age. Two teachers worked in private schools and the others in public schools in the region of Lisbon (PT), Porto Alegre (BR), and Santa Maria (BR). Teachers had an average of 9.33 years school experience, being the least 2 years and the maximum 27 years. Two educators worked with 3 year old children, two worked with 4 year olds, two worked with 5 year olds, and one worked with children from 1 to 5 years and another worked with children from 3 to 5 years. All had childhood education training and always actuated in kindergarten.

\section{Results}

This section exposes the results obtained when investigating the teachers' perceptions about giftedness and special needs. The analysis was developed according to a content analysis procedure though an inductive categorization which was theoretically based [6]. The organization divides the data into categories, subcategories, indicators and frequencies, and gathers the discourses of all the teachers about different characteristics and specific subjects into units of significance.

\subsection{Results about giftedness}

According to teachers' answers, some children can be considered as gifted. Specifically in this study, the most important characteristics observed for screening were differentiation rhythm and interests (Table 1 and 3). In relation to the process of identification, teachers state that behavior and performance of children are the specific variables that are most observed (Table 2). The teacher's answers about the special needs recognized in children in the educational process specify the behavior of the student and the perceptions of teachers about the student (Table 5). The analysis of the teachers' discourses also acknowledge that the perception of giftedness and the perception of special needs are similar according to teachers' understanding about their subjects.

Table 1. Indicators of teachers' perception of giftedness

\begin{tabular}{|c|c|c|c|}
\hline Subcategory & Indicator & Description & $\mathrm{F}$ \\
\hline \multirow{9}{*}{ Perception } & \multirow{3}{*}{ Psychological } & $\begin{array}{l}\text { Specific } \\
\text { characteristics of the } \\
\text { student }\end{array}$ & 3 \\
\hline & & $\begin{array}{l}\text { Specific } \\
\text { characteristics of } \\
\text { giftedness }\end{array}$ & 4 \\
\hline & & Styles of expression & 2 \\
\hline & Social & Isolation & 1 \\
\hline & \multirow{5}{*}{ Educational } & $\begin{array}{l}\text { Engagement related } \\
\text { to interests }\end{array}$ & 3 \\
\hline & & $\begin{array}{l}\text { Diversity of } \\
\text { production }\end{array}$ & 1 \\
\hline & & Diverse interests & 1 \\
\hline & & $\begin{array}{l}\text { Pace of } \\
\text { learning/performance }\end{array}$ & 3 \\
\hline & & Anxiety for learning & 2 \\
\hline \multirow{7}{*}{$\begin{array}{c}\text { Not } \\
\text { perceived }\end{array}$} & \multirow{3}{*}{ Psychological } & Need of diagnosis & 3 \\
\hline & & $\begin{array}{l}\text { Lack of evaluation } \\
\text { instruments }\end{array}$ & 2 \\
\hline & & Scarce information & 3 \\
\hline & \multirow{4}{*}{ Educational } & $\begin{array}{l}\text { Benefit from } \\
\text { academic } \\
\text { performance (not } \\
\text { related to giftedness) }\end{array}$ & 2 \\
\hline & & Identifying a child & 1 \\
\hline & & $\begin{array}{l}\text { Association for other } \\
\text { special needs }\end{array}$ & 1 \\
\hline & & Age group & 1 \\
\hline
\end{tabular}


The results show that teachers perceive giftedness in three dimensions: psychological, social and educational. The specific characteristics of giftedness are the base for identifying a gifted child's psychological feature. Engagement associated to interest and pace of learning/performance are the most relevant differences that teachers observe in the educational aspects. Isolation is the only social indicator perceived in gifted children. The data also show that teachers do not perceive giftedness in two dimensions: psychological and educational, more specifically, they do not separate these two dimensions. Two points are considered the most difficult in the process of evaluating children: a) the necessity of a specific diagnostic, b) the benefits of academic performance (not related to giftedness), in accordance with results from Table 1 .

Table 2. Subcategories and indicators of giftedness

\begin{tabular}{|c|c|c|c|}
\hline Subcategory & Indicator & Description & $\mathrm{F}$ \\
\hline \multirow[t]{2}{*}{ Difference } & Behavior & $\begin{array}{l}\text { Differentiated } \\
\text { behavior }\end{array}$ & 4 \\
\hline & Needs & distinct needs & 4 \\
\hline \multirow{3}{*}{ Specifities } & $\begin{array}{l}\text { Observation } \\
\text { (at teachers) }\end{array}$ & Specificities & 7 \\
\hline & Singularity & $\begin{array}{l}\text { Positive } \\
\text { characteristics } \\
\text { for an } \\
\text { educational } \\
\text { process }\end{array}$ & 2 \\
\hline & Characteristics & $\begin{array}{l}\text { Specific } \\
\text { observation }\end{array}$ & 2 \\
\hline \multirow{3}{*}{ Recognize } & Diagnosis & $\begin{array}{l}\text { Recognize for } \\
\text { performance }\end{array}$ & 4 \\
\hline & $\begin{array}{l}\text { Difficulty (for } \\
\text { teacher) }\end{array}$ & $\begin{array}{l}\text { Difficulty } \\
\text { recognition of } \\
\text { signalization }\end{array}$ & 3 \\
\hline & $\begin{array}{l}\text { Performance } \\
\text { (of child) }\end{array}$ & $\begin{array}{l}\text { Flawed } \\
\text { recognition } \\
\text { for good } \\
\text { performance }\end{array}$ & 1 \\
\hline
\end{tabular}

The perception of 7 of the 8 participants in this study is related to the specificity of the characteristics of giftedness in a child. From the above mentioned indicators three of them may be highlighted: differentiated behavior, needs and recognition by performance due to their high frequency.

\subsection{Results about gifted students}

In this section, we present the results on the perception of teachers for the definition of a gifted student and his/her characteristics.

According to these results, teachers observe the gifted child considering three factors: selfmanagement of learning; cognition and behavioral/social skills. Moreover, their perception about giftedness is associated to interests, curiosity and different paces and rhythms of learning.
Table 3. Characteristics of the perception of giftedness

\begin{tabular}{|c|c|c|}
\hline Subcategory & Characteristic & $\mathrm{F}$ \\
\hline \multirow{5}{*}{$\begin{array}{c}\text { Self } \\
\text { management of } \\
\text { learning }\end{array}$} & Different interests & 4 \\
\hline & Pleasure for research & 2 \\
\hline & Autonomous learning & 2 \\
\hline & Curiosity & 3 \\
\hline & $\begin{array}{l}\text { Request for activities } \\
\text { / tasks }\end{array}$ & 1 \\
\hline \multirow{7}{*}{ Cognition } & Different paces & 3 \\
\hline & Agility in learning & 2 \\
\hline & High ability & 1 \\
\hline & Good performance & 2 \\
\hline & Creativity & 1 \\
\hline & $\begin{array}{l}\text { Association of } \\
\text { contents and } \\
\text { experiences }\end{array}$ & 1 \\
\hline & $\begin{array}{l}\text { Differentiated } \\
\text { thinking }\end{array}$ & 1 \\
\hline \multirow{8}{*}{$\begin{array}{l}\text { Behavioral/ } \\
\text { Social }\end{array}$} & Agitation & 1 \\
\hline & Exemplar behavior & 1 \\
\hline & Distraction & 1 \\
\hline & Effort & 1 \\
\hline & Concentration & 1 \\
\hline & Engagement & 1 \\
\hline & Perfectionism & 1 \\
\hline & $\begin{array}{c}\text { difficulties in } \\
\text { Interaction with peers }\end{array}$ & 1 \\
\hline
\end{tabular}

According to these results, teachers observed the perception of gifted child in two subjects: the child and the teacher. The first subject described by the teachers is about motivation, difficulty, specificity, exclusion and the difference that teachers recognize in the performance of gifted children when compared to their peers.

Table 4. Subcategories and indicators of perceptions of gifted child

\begin{tabular}{|c|c|c|c|}
\hline Subcategory & Indicator & Description & $\mathrm{F}$ \\
\hline Motivation & \multirow{9}{*}{ Child } & To learn & 1 \\
\hline Difficulty & & With peers & 1 \\
\hline \multirow{2}{*}{ Specificity } & & Engagement & 3 \\
\hline & & Interest & 3 \\
\hline \multirow{4}{*}{ Difference } & & Pace of learning & 7 \\
\hline & & Interests & 4 \\
\hline & & Activities & 4 \\
\hline & & Behavior & 4 \\
\hline Exclusion & & Isolation/ solitary & 1 \\
\hline Motivation & \multirow{3}{*}{ Teacher } & Promotion & 1 \\
\hline Difficulty & & $\begin{array}{c}\text { Perceive the } \\
\text { Desynchronization }\end{array}$ & 1 \\
\hline Difference & & $\begin{array}{c}\text { Perception the } \\
\text { behavior }\end{array}$ & 2 \\
\hline
\end{tabular}

Participants claim that to undertake a specific and thorough observation of the characteristics within these subcategories is necessary more information and knowledge. For these teachers it is necessary to attend to and observe the behavior, the learning and the performance of the children. This observation is a contribution for recognizing and subsequently understanding the gifted child in preschool.

In the second focus, it is possible understanding which perception the teacher have about him/herself. 
Teachers describe the specific necessities of theirs performance in the classroom. The perception of gifted child is related to the promotion of motivation, the concept of desynchronization and the perception of behavior.

\subsection{Results about special needs}

Furthermore the description of these teachers specifically in what concerns inclusion and the recognized of special needs in the children was analyzed and summarized in Table 5.

Table 5. Subcategories and indicators of special needs

\begin{tabular}{|c|c|c|c|}
\hline Subcategory & Indicator & Description & $\mathrm{F}$ \\
\hline \multirow{4}{*}{$\begin{array}{c}\text { Student } \\
\text { (Specifies) }\end{array}$} & \multirow{2}{*}{ Behavior } & $\begin{array}{c}\text { Differentiated } \\
\text { performance }\end{array}$ & 5 \\
\cline { 3 - 4 } & & $\begin{array}{c}\text { Difficulties of } \\
\text { comprehension }\end{array}$ & 2 \\
\cline { 3 - 4 } & & $\begin{array}{c}\text { Involvement in } \\
\text { the task }\end{array}$ & 5 \\
\hline \multirow{2}{*}{$\begin{array}{c}\text { Teacher } \\
\text { (professional) }\end{array}$} & \multirow{2}{*}{ Knowledge } & $\begin{array}{c}\text { Specific } \\
\text { knowledge }\end{array}$ & 1 \\
\cline { 3 - 4 } & & $\begin{array}{c}\text { Specific } \\
\text { training }\end{array}$ & 2 \\
\cline { 3 - 4 } & & $\begin{array}{c}\text { Understanding } \\
\text { the student } \\
\text { action }\end{array}$ & 7 \\
\cline { 3 - 4 } & & Diagnostic & 2 \\
\hline
\end{tabular}

Accordingly the analysis of the data indicates that the teachers understand and recognize the special needs of the gifted in a way which is similar to the perception of the gifted child.

This similar perception of the teachers is because they are using the same indicator. For the teachers, the perception of gifted student and his/her special needs is about the children and the teacher. In the case of children. The teachers understand the special need is present in the student's behavior. And the recognition of special needs happens through a differentiated performance, difficulties in understandings and the kind of the involvement in the task.

In the case of teachers, they understand the way the child reacts to learning, to development and to teaching. In others words, for teachers the relevance is knowledge. If the teacher knows about inclusive education and special needs, he/she has specific training and understanding of the student's action that makes the diagnostic possible. For the teachers, the indicators of special needs demand specific training and deep knowledge about this subject. The recognition of a special need or of a gifted student is mainly developed though the behavior of the children.

In sum, the analysis of the tables shows that teachers use their understanding about the development of the children to differentiate when children present different characteristics that are relevant to recognize giftedness. Through of characteristics such as pace of learning or behavior and task commitment the teachers perceive giftedness in a child. However what the teacher needs to do after recognize this specific development is more complex. According to teachers it is difficult to acknowledge what the child needs and what should be done to motivate and stimulate him/her.

\section{Discussion}

In this section, we discuss the results derived from the content analysis of interviews with the preschool teachers about giftedness, gifted children and their special needs. Specifically, the discussion compares the results from this study with those from other researches. A teacher should signalize giftedness in preschool children through their characteristics, specificities and development [17]. And a teacher should also understand which are the psychological dimensions that have an important position in the process of recognition the giftedness [2, 3, 17]. According to the teachers who participated in this research, the psychological dimension is most important reference for the signalization and recognition of a gifted student. Because for the teachers the recognition of psychological characteristics in the screening of the gifted student is important in the evaluation. But in the same description theirs was described which to recognize the characteristics psychological is very difficult for the teachers.

These results suggest comprise the behavior, the development and the learning of the student in evaluating giftedness. This is similar to what happens when teachers need to help and incentive a gifted student when teaching him/her [19]. The problem is not about the perceptions of giftedness, the problem is what he/she needs to do with the gifted student $[17,19]$.

\subsection{The gifted students}

The present study suggests that teachers perceive giftedness as a different behavior in child development. Additionally, the teachers describe giftedness through characteristics present in the literature across different frames of reference (e.g., $[3,15])$.

Cognitive abilities are described as relevant by the teachers. The teachers outline attention, pace and autonomy as abilities comprising the personality of a gifted child, similarly to the study of Havigerová and Haviger [12].

When teachers describe their conceptions and perceptions about inclusion or inclusive education in this study, a specific situation emerges: it is necessary understanding the special needs. If the teacher does not know about inclusion, do not have a 
specific training, and misunderstands the student behavior, the inclusive education is not practiced [1, $3,5,20]$. So the teachers who understand what special needs and that absorb knowledge of the concept of inclusion evaluate better their student according to differentiated learning rhythms [5, 20].

For the participants of this study giftedness and special needs have a similar description. According to the teachers for student must be recognize as gifted is necessary a diagnostic, and an analyze about the specificity of psychological and educational student characteristics. In case of special needs is necessary a diagnostic and a knowledge about the specificity about behavior and the school performance. Required of the teachers a knowledge about the individually learning and differentiated [1, $2,5,19]$.

The characteristics described by the teachers in the results converge with those described by Renzulli [18]. According to the Three Ring Model theory, a gifted student has different interests, curiosity, different paces, agility in learning, pleasure for research, autonomous learning, and good performance [18]. These characteristics are listed by the teachers too, exposing that they understand the characteristics which compose the concept of giftedness.

In this process of defining the characteristics of giftedness, teachers describe that three subcategories are important in the perception of a gifted student: self-management of learning, cognition, and behavioral/ social. These characteristics are in accordance with those described by Gagné [10] about the giftedness as a natural ability which the student expresses in his/her development and performance at the school. Such abilities and natural skills are observable in the behavioral or social actions and in the self-management of learning, when not trained [10].

\subsection{The concept of giftedness}

The perceptions of the concept of giftedness from our study are similar with others researches, which had the purpose to understand what is the teacher perception on the gifted student $[3,7,12,15]$.

The teachers described that the motivation is necessary to recognize the gifted student and too for learning of these student. So is possible which the gifted student be different in relation to the activities, isolation, engagement, interest and the promotion of the learning. Teachers need to understand the specificities or the differences of behavior and student's needs to recognize the giftedness [7, 12].

Gagné [10] describes the importance of the catalysts. For him, the motivation expressed for the interests and the attitudes regarding to the personality of the gifted student, and in school this have a relevance about the recognize at giftedness. And the teachers describe these two subjects.

According to the teachers, environmental and psychological are variables involved in the school, and for a teacher to recognize a gifted student he/she needs to evaluate the performance of the student with regard to actions in the environmental and engagement in the tasks.

This study suggests that teachers perceive what to stimulate the global development of child, what teachers need to do and is necessary to respect the student's characteristics, promoting diverse and meaningful learning experiences. This specificity in the evaluation at the catalysts about what are natural abilities and skills in the individual development and what is training in relation at the educational and performance of the student.

\subsection{Giftedness and the school}

According to the teachers, the perception of giftedness in the educational indicator are: the engagement related to interests, diversity of production, diverse interests, pace of learning/ performance, anxiety of learning. Gagné describes that these characteristics represent the development process which involve progress, activities and investment that student have in the school [10].

The results exposed that teachers in the preschool understand the concept of giftedness, but are not sure about what is specific to perceive and teach in the school with gifted students. Renzulli [18] describes that when the concept is accepted and understood is easier to recognize a gifted student. However, if a teacher do not know what happens after the signalization or recognition of giftedness, normally the student do not feel in the school an inclusion process or an inclusive education according to their needs.

Recognize giftedness is possible for the preschool teachers, the problem is about the psychological process or, according to Renzulli, is about the enrichment [18].

Students who manifest or are capable of expressing the giftedness require a wide variety of educational opportunities and services that are not ordinarily provided through regular instructional programs [18].

Therefore teachers need to have a perception about giftedness, and it involves a comprehensive methodology about gifted students and their specificities. Inclusion and giftedness are an educational policy for teachers perceive what a special need is and what the student needs. Sometimes, this is the problem.

According to the results of this study, the perceptions of teachers involved characteristics, catalysts, environmental and psychological variables about the student and the school. The difficulty 
resides on happens after the recognized and perceived the gifted children.

According to these teachers identifying giftedness is not easy. Although teachers know the concept, they are not secure about the identification process. The differentiation of behavior and learning is significantly important for the teachers. However in their academic training, preschool teachers do not extend information about how to identify and engage the gifted child [3, 4, 12, 15].

In the global of this research, the results indicated that teachers of preschool have a differences between groups of teachers. The comparison between the nationalities, the years of experience and training revealed some differences in the teachers' perceptions.

The main differences between the two countries was the focus teachers give to the academic characteristics of theirs gifted students. In Brazil, the knowledge that educational professionals express about giftedness reveals that their perceptions are about the academic development and student academic performance. They consider also myths about the way through which the student expresses and exposes his/her potential. In Portugal preschool teachers believe that giftedness also has negative characteristics related to school performance, because the gifted learner may not feel motivated or encouraged during his/her process of learning and development. Brazilian preschool teachers tend to perceive giftedness taking into account the dimension of Adaptability, whereas teachers from Portugal tend to focus on the Nonconformity dimension.

Teachers with longer work experience tend for more perceive the characteristics of nonconformity dimension to be related to giftedness.

Teachers who have participated in specific training activities in the theme of inclusive education do not perceive giftedness and gifted characteristics in a different way, thus have similar opinions and discourses to those who have not participate in training activities.

\section{Conclusion}

The analysis in this study exhibit what teachers' understanding and perception about the giftedness in the preschool. Some authors described in their research what teacher's represent the giftedness is a special need and a specific characteristic on the development and the learning in different school levels $[3,4,7,8]$.

The results of this research express that: a) teachers know the concept of giftedness; b) they analyze engagement and behavior of the children; c) some children have characteristics of giftedness, d) teachers do not always know what is needed for the development of these specific children, e) teachers consider difficult to understand the needs of gifted children, f) teachers understand the giftedness as being a special need, g) the gifted student needs an inclusive education.

Last but not least, this study indicates that teachers' academic and practical training needs to be more specific about the concept and the identification of gifted children in preschool, and their motivation with further training on the needs and specifities of the gifted. This statement complements other studies on different school periods with similar conclusions $[3,4,12,15]$.

\section{Acknowledgement}

This research was financially supported by the Conselho Nacional de Desenvolvimento Cientifico e Técnológico (CNPq-GDE, Brazil) through the program GDE (Doutorado Pleno no Exterior) grant number 200984/2011-0.

\section{References}

[1] Ainscow, M. C., E. Paes, I. Micaelo, M., \& T. Vitorino. Aprender com a diversidade: um guia para o desenvolvimento da escola. $2^{\mathrm{a}}$. Lisboa: ACIDI, 2011.

[2] Almeida, L.S., D.S. Fleith, e E.P. Oliveira. Sobredotação: Respostas Educativas. ADIPSIEDUC, Braga, 2013.

[3] L.S. Almeida, E. P. Silva, E.P. Oliveira, C. Palhares, A.S. Melo, e A. Rodrigues. "Conhecimenteo e Perceções dos Professores na Área da Sobredotação." Sobredotação, 2001, pp. 139-153.

[4] T.R. Bahiense, e C.B. Rossetti. "Altas Habilidades/Superdotação no Contexto Escolar: Percepções de Professores e Prática Docente." Revista Brasileira de Educação Especial, 2014, pp. 195-208.

[5] Bahia, S., \& E. Oliveira. "Diferenças Individuais e Necessidade de Aprendizagem". In Psicologia da Educação: Teoria Investigação e Aplicação by F.H. Veiga, pp- 583-631. Climepsi, Lisboa, 2013.

[6] Bardin, L., Análise de Conteúdo. 5. Edições 70, Lisboa, 2010.

[7] E. Corte, "Giftedness considered from the perspective of research on learning and instruction." High Ability Studies, 2013, pp. 3-19.

[8] T.L. Cross, e L.J. Coleman. "School-Based Conception of Giftedness." Journal for the Education of the Gifted, 2014, pp. 94-103.

[9] C. Esteban, A. Sánchez, e M. Sánchez. "El desarrollo físico, cognitivo y lingüístico en la educación infantil (3-6 
años)." Em Psicología de la educación y del Desarrollo en contextos Escolares, de M. Torres, \& J. Cruz, pp. 193-216. Ediciones Pirámide, Madrid, 2006.

[10] Gagné, F., "The DMGT: Changes within, beneath, and beyond." Em Altas Habilidades/Superdotação (AH/SD): Criatividade e Emoção, de F.H.R. Piske, J.M. Machado, S. Bahia, \& T. Stoltz, pp. 19-42. Juruá Psicologia ABDR, Curitiba, 2014.

[11] Gallagher, J.J., "Psychology, Psychologists, and Gifted Students." In Handbook of giftedness in Children: psychoeducational theory, research, and best practices, by S.I. Pfeiffer, pp. 1-11. Springer Verlag, New York, 2008.

[12] J.M. Havigerová, J. Haviger. "Where preschool children acquire information about a topic theu enjoy: giftedness-based study." Procedia, 2014, pp.219-224.

[13] K.A. Heller, "Identification of Gifted and Talented Students.” Psychology Science, 2004, pp. 302-323.

[14] Heller, K.A., F.J. Mönks, R.J. Sternberg, e R.F. Subotnik. International Handbook of Giftedness and Talent. $2^{\circ}$. Pergamon, London, 2002.

[15] R.R. Maia-Pinto, D.S. Fleith. "Percepção de Professores sobre Alunos Superdotados." Estudos de Psicologia, 2002, pp.78-90.

[16] Pérez, S.G.P.B., S.N. Freitas. "Encaminhamentos Pedagógicos com Alunos com Altas Habilidades/ Superdotação na Educação Básica: Cenário Brasileiro." Educar em Revista (UFPR), 2011, pp.109-124.

[17] Porter, L. Gifted Young Children: a guide of teachers and parents. $2^{\mathrm{a}}$. Open University Press, Buckingham, 2005.

[18] J.S. Renzulli, "Emerging Conceptions of Giftedness: Building a Bridge to the New Century." Exceptionality: A Special Education, 2010, pp. 67-75.

[19] M. Shaw, "Working with Gifted Children." National Childcare Accreditation Council, 2009, pp. 24-26.

[20] Tomazzi, G.M. "Competência, qualificação - O correto?". In Para uma Escola do Século XXI by M.T.E. Mantoan, pp. 47-51. UNICAMP, Campinas, 2013. 